\title{
An Environmentally Extended Input-Output Analysis to Support Sustainable Use of Forest Resources
}

\author{
Tuomas Mattila $^{*}, 1$, Pekka Leskinen ${ }^{1}$, Ilmo Mäenpää ${ }^{2}$ and Jyri Seppälä ${ }^{1}$ \\ ${ }^{I}$ Finnish Environment Institute SYKE, Research Program for Production and Consumption \\ ${ }^{2}$ University of Oulu, Thule Institute, Finland
}

\begin{abstract}
The use of environmentally extended input-output analysis was demonstrated for quantifying the overall sustainability impacts of forest industries in the Finnish economy in 2005. Direct greenhouse gas emission, land use, employment and import impacts of economic sectors were transformed into impact intensities of products. The intensities were used to construct a final demand based emission inventory demonstrating the relative importance of export, investment and consumption activities in causing environmental and social impacts. The calculations were presented using an aggregated input-ouput table, which makes it possible to repeat the calculations using standard spreadsheet software. Therefore the study can be used as an accessible primer to the use of input-output methods in sustainability assessment.
\end{abstract}

Keywords: Environmentally extended input-output analysis, land use, climate change, multiple criteria decision analysis.

\section{INTRODUCTION}

The global forest sector is under structural change due to a relocation of paper production plants and an increase of forest bioenergy and wooden construction materials production. Evaluation of the sustainability impacts of this change in production requires the development of different quantitative scientific tools (c.f. $[1,2])$. The evaluation is limited by the complexity of supply chain interactions and also by the different definitions given to sustainability in general. Sustainable use of forest resources become an important topic in forestry after the United Nations (UN) Conference on Environment and Development in Rio [3]. Sustainability is a multi-dimensional concept and it includes economic, ecological, social and cultural dimension. As such, the different dimensions of sustainability are vague. In practical applications, the general criteria are typically measured by more concrete indicators such as economic profitability, biodiversity, climate change impacts and employment. Therefore a tool for evaluating sustainability of structural change should be able to present the different dimensions of sustainability simultaneously.

The environmental, economic and social impacts of forest industries are well known. However the direct impacts of an industry may only be a tip of the iceberg, compared to the indirect impacts caused in the supply chain [4]. In environmental sustainability assessment of products, life cycle assessment has been the method of choice for quantifying these impacts [5]. In macroeconomics, these supply chain impacts are quantified as multiplier effects and are routinely calculated for employment and value added $[6,7]$, but in an increasing manner also for environmental

Address correspondence to this author at the Finnish Environment Institute, P.O.Box 140, FI-00251 Helsinki, Finland; Tel: + 358400148 769; Fax: +358 95490 2391; E-mail: tuomas.mattila@ymparisto.fi emissions $[4,8,9]$. There is also an increasing literature on combining the product and economic level analyses into hybrid input-output life cycle assessment [10].

Environmentally extended input-output analysis (EE-IO) was described already in 1970 by Leontief [11] (who originally invented economic input-output analysis and was awarded with the Nobel prize of economics). EE-IO incorporates environmental emissions or processes to the economic tables of the national accounts. A few examples of the application of EE-IO into national statistics are the NAMEA (national accounting matrix including environmental accounts) tables developed in the Netherlands [12] and the German PIOT (physical input output table)[13]. In addition a few EE-IO datasets have been developed by independent researchers for example for USA [8], Japan [14] and Finland [15]. Also the global trade analysis project (GTAP) includes emission inventories in addition to economic interactions between nations [16]. In recent years the combination of input-output tables with life cycle assessment [5] has increased the use of this method for product level sustainability assessment $[10,17]$ as well as the analysis of the environmental impacts of consumption and global trade [18].

The purpose of this paper is to demonstrate the use of environmental input-output analysis in the sustainability assessment of forest industry. We present how EE-IO can be used to assess supply chain effects with multidimensional sustainability impacts in a concise and transparent manner. The following section gives an overview of the basic EE-IO equations, which are then applied to a simplified case of the Finnish economy in 2005, with an emphasis on forest industry. Results are presented on the ecoefficiency of forest industry, on the overall impacts of forest products in the national economy and on the possibility of using inputoutput analysis data as a background for detailed life cycle assessment. 


\section{MATERIALS AND METHODS}

\section{Overview of Environmental Input-Output Analysis}

This chapter presents and overview of the economic input-output analysis and its extension to environmental systems. A more detailed review of the development of the modeling approach is given for example in [7] or [9]. EUROSTAT has published a guide for compiling and using economic input-output tables [19] and economic tables are readily available for application from EUROSTAT [20] and OECD [21].

The main research topic of economic input-output analysis is the relationship between the scale of production output $(x)$ and the final demand of products $(f)$. This relationship can be expressed with an equation, which also takes into account the demand for products caused by the production itself:

$$
x=A \cdot x+f
$$

where the intermediate demand is expressed in a matrix $A$. It describes the amount of products needed from other (and from the producing) sectors for the production of one unit of product. It is a square matrix with dimensions equal to the amount of sectors in the model. (The scale of production $x$ and the final demand $f$ are vectors with a length equal to the amount of sectors.) In the system of national accounts, the columns of the input-output table describe purchases (debts) and rows describe sales (credits) [7]. The input-output table (in $\mathrm{M} €$ ) is transformed into the $A$-matrix (in $\mathrm{M} € / \mathrm{M} €$ ) by dividing each column (purchases by sector from all sectors, i.e. input, $\mathrm{M} €$ ) with the sum of the corresponding row and final demand (total sales or production, i.e. output, M€). A basic assumption in input-output analysis is that the relationship between demand and production is linear and no thresholds exist. Therefore the model applies well to allocating production impacts to demand categories, but has limited scope for prediction, since the assumption of linear response to change is easily violated in nonlinear real-world systems if the change becomes sufficiently high.

The eq. (1a) can be re-arranged to give the relationship between total production and final demand:

$$
x=(I-A)^{-1} f
$$

where the matrix $(\mathrm{I}-\mathrm{A})^{-1}$ is known as the Leontief inverse. Each column of the matrix describes the economic activity resulting in the economy following the production of one unit of monetary product in a given sector. The column sums are also known as (backward) multiplier effects [7] and are used for example to identify the key sectors of an economy [6].

While the economic model described in equations (1a) and (1b) is conceptually simple, it may have very large matrices. For example the Japanese [14] and US [8] tables include more than 400 sectors. National accounts in Europe are usually reported in a 58 sector resolution. With increasing resolution, the amount of overall production remains the same, but the allocation of production activities to demand gets more accurate [22]. However understanding of model complexity become limiting when matrix size is increased. In addition the inversion of large matrices requires special software, which are not as commonly accessible as spreadsheet calculators. In order to keep the model understandable and calculations easily repeatable, in the input-output table used in this study only the forest industry sectors were kept at a detailed level, while other sectors were highly aggregated.

If the emissions of economic sectors are known, equation (1b) can be extended into a environmental input-output analysis by simple matrix multiplication [17]:

$g=B(I-A)^{-1} f$

where $g$ are the overall emissions caused by the final demand and $B$ is a matrix of emission intensities (emission type by industrial sector). The emission intensities can readily be calculated from reported annual emissions by dividing each column with the production output of the corresponding sector. If $f$ is replaced with a diagonal matrix with the values of $f$ at the diagonal, equation (2) will yield a matrix of emissions caused by production of final demand items.

In the form presented in equation (2) the model does not include the emissions caused outside the national boundaries, which are sometimes called the "emissions embodied in imports" [18]. They can however be included in the EE-IO framework in order to construct consumption based emission inventories, where emissions are allocated to the consumers of goods. In the consumption based inventory, emissions embodied in imports are added to the national emissions and the emissions associated with export production (whether of domestic origin or embodied in imports) are removed from the inventory through the use of input-output analysis. The resulting figure describes the emissions caused globally by the production of goods for consumption in the studied country. Multiple region input-output (MRIO) models have been used to make these assessments with notable differences in the magnitude of emissions and mitigation options [23]. As the model presented in equation (2) does not include imports, it cannot be used to construct a consumption based inventory directly. However it can be used to quantify the extent of domestic impacts caused by export activities, as demonstrated later in this article.

An interpretation of equation (2) is that it describes the emissions (or other impacts) caused throughout the supply chain of producing the final demand items. If the final demand vector is replaced by a unit matrix (or left out completely), equation (2) will give the total emissions caused in meeting a unit of demand. The complex interactions and economic loops of production are completely captured with the Leontief inverse and there is no "cut-off" of processes [24], which limits conventional process based life cycle assessment [10]. Therefore environmental input-output analysis can be thought of as a simple method for producing life cycle assessments of services and products [8]. Compared to traditional process based life cycle assessments, it can be made with less resources, but it also has been found to be more comprehensive, since emissions caused by services and machinery are also included $[9,10]$.

Because of the simple linear structure, operations from linear algebra can be used to analyze the system. Some of the more common analyses are the analysis of sensitivity and 
contribution of different industries to emissions [24], decomposition of observed temporal change [25], identification of key sectors [6] and the extraction of main impact pathways [26]. These advanced topics of analysis were not included in this study. Instead the focus is on demonstrating the basics of environmentally extended inputoutput analysis and its application to sustainability analysis.

In this study we applied the basic environmentally extended input-output analysis described above to the Finnish economy in the year 2005 [15]. Forest industries are compared to other economic sectors by their direct and multiplier impacts. Also the contribution of different final demand categories (consumption, export and investments) to sustainability indicators is studied. In addition, the use of environmental input output analysis in hybrid life cycle assessment $[10,17]$ is demonstrated.

\section{Data Sources for Emissions and Economic Interactions}

The data used in this study was based on the ENVIMATproject [15], where a highly detailed environmentally extended input-output table of Finland 2002 and 2005 was constructed. However for the purposes of demonstrating the role of forest industry in sustainability, the detailed data was aggregated. This chapter describes the data sources used in the ENVIMAT-study and the procedure of (and limitations caused by) aggregation.

The ENVIMAT study used the official economic supply and use tables [27] as the starting point. Those are regularly assembled by the statistical office as a part of the system of national accounts and are available for several countries from OECD and EUROSTAT databases. However since their function is economic accounting, the classification of sectors was adjusted to better suit environmental assessment. Several service sectors were merged and some industrial sectors were disaggregated. Details are given in [15]. Some of the most important new classifications were the separation of animal farming from crop production and fertilizer industry from basic chemicals. This resulted in a classification of 150 industries, which was used to construct an industry-by-industry input-output table using the fixed product sales structure assumption [19]. In this study this high level of detail was kept only for the forest industries, all other industries were aggregated into 14 macroeconomic sectors.

The aggregation of detailed data introduced errors in calculation [22]. For example, in the aggregated table agriculture included animal, grain and vegetable production. Starch purchased by the pulp and paper industry was accounted as input from the agricultural sector, and therefore a fraction of the methane emissions of animal agriculture was allocated with that purchase. Similarly purchases from metal industry resulted in an allocation of emissions from both ferrous and nonferrous metals. More accurate results could be obtained by the 150 industry division of the ENVIMAT -study [15], but the representation of calculation would have been more complex. Therefore inaccurate, but relatively simple results were presented in this study.

In addition to aggregation of economic sectors, also the amount of environmental interventions in the ENVIMATmodel was reduced for this study. From the environmental impacts considered in the ENVIMAT (e.g. climate change, acidification, human toxicity, ecotoxicity, eutrophication, land use, ozone depletion and depletion of mineral resources) only climate change and land use were chosen to represent environmental sustainability, while employment and value added were chosen for social sustainability. Several other alternatives for environmental indicator combinations would have been possible, but land use and climate change were chosen to represent the main differences between forest and other industries. The greenhouse gas emissions were based on the greenhouse gas inventory and energy statistics of the statistical office [28]. Separate gases (carbon dioxide, methane, nitrous oxide and F-gases) were aggregated into global warming potential $\left(\mathrm{CO}_{2} \mathrm{e}\right)$ using the IPCC 2007 characterization factors [29]. Land use was estimated by allocating CORINE land cover data [30] to economic sectors based on agricultural and forest statistics and physical and economic production [31]. Employment and value added were based on the national account tables [27].

The aggregated environmentally extended input-output table is presented in Table $\mathbf{1}$. The aggregated table is supplemented with final demand in three subcategories (domestic consumption, investments and exports) and the satellite accounts of greenhouse gas emissions, gross domestic product, employment and land use are presented below the economic input-output table. Imports to industries were not aggregated into the table, but were kept as a separate satellite account for transparency. Also as mentioned before, the emissions embodied in imports were not included in the analysis.

\section{RESULTS}

\section{Economic and Environmental Multiplier Effects of the Finnish Forest Industry}

The central role of forest industries in the national economy could be observed from the input-output table (Table 1). Most of the forest industry sectors have a large share of export production and a high volume of export. Especially pulp and paper industry is strongly connected to the rest of the economy and within the forest industries. The main interactions of that sector are within itself (sales between companies belonging to the same industrial sector), and with chemicals, metals, forestry and transport. In addition the pulp and paper industry purchases goods from and sells products to other forest industry sectors.

The columns of the Leontief inverse provided a quantification of the overall structure presented in the previous paragraph (Table 2). For purchases of sawn wood, one $\mathrm{M} €$ of final product would result in more than 2.1 M€ of economic activity (the average multiplier for all sectors was 1.8). From the corresponding column it can be read, that most of the activity is focused on the sawmilling industry, but a significant portion occurs also in forestry and logging, trade services and transportation. A similar pattern could be observed for the pulp and paper industry, however with less economic impacts to forestry and more to chemicals and metals industries and to transport. The high multiplier for the pulp and paper industry's own demand demonstrates the 
Table 1. An Aggregated Environmentally Extended Input Output Table of the Finnish Economy, Focusing on Forest Industries. Satellite Accounts Include Imports into Industries, Greenhouse Gas Emissions (GHG), Gross Domestic Product (GDP), Employment and Land Use. The Input-Output Table Describes Sales from the Row Industry to the Column Industry

\begin{tabular}{|c|c|c|c|c|c|c|c|c|c|c|c|c|c|c|c|c|c|c|c|c|c|c|c|c|c|}
\hline $\begin{array}{r}\text { Input-C } \\
\text { at B } \\
\text { Price }\end{array}$ & $\begin{array}{l}\text { Output } \\
\text { Basic } \\
\text { es M€ }\end{array}$ & - & $\sim$ & $m$ & تั & $\begin{array}{l}\text { હे } \\
\text { ב్ }\end{array}$ & $\frac{\bar{\Xi}}{\bar{\Xi}}$ & 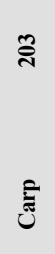 & 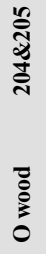 & 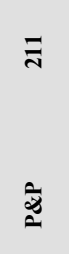 & $\stackrel{\infty}{a}$ & 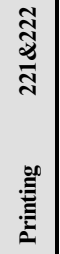 & Ë & ह & 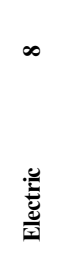 & $\stackrel{\grave{\Xi}}{0}$ & 预 & 产 & $\begin{array}{l}\frac{1}{\infty} \\
\infty\end{array}$ & $\stackrel{\mathscr{E}}{\tilde{E}}$ & $\Xi$ & $\begin{array}{l}n \\
2 \\
0 \\
0 \\
0\end{array}$ & 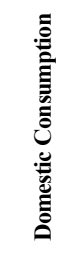 & 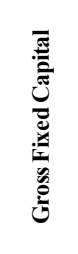 & $\stackrel{n}{\frac{0}{2}}$ \\
\hline 1 & Agriculture & 963 & 0 & 0 & 2,246 & 1 & 0 & 1 & 0 & 3 & 0 & 3 & 7 & 8 & 19 & 3 & 2 & 7 & 80 & 13 & 13 & 58 & 622 & 163 & 371 \\
\hline 2 & $\begin{array}{c}\text { Forestry } \\
\text { and logging }\end{array}$ & 0 & 580 & 2 & 0 & 1,183 & 186 & 72 & 3 & 833 & 0 & 0 & 2 & 0 & 0 & 2 & 33 & 9 & 0 & 1 & 0 & 0 & 161 & 101 & 57 \\
\hline 3 & Mining & 1 & 1 & 143 & 3 & 1 & 0 & 3 & 0 & 127 & 0 & 0 & 193 & 150 & 4 & 2 & 180 & 162 & 3 & 1 & 1 & 6 & 8 & 5 & 138 \\
\hline 4 & $\begin{array}{c}\text { Food } \\
\text { products }\end{array}$ & 471 & 4 & 6 & 1,380 & 11 & 3 & 8 & 1 & 68 & 4 & 29 & 101 & 124 & 189 & 28 & 24 & 44 & 916 & 93 & 85 & 376 & 3,312 & 99 & 1,240 \\
\hline 201 & $\begin{array}{l}\text { Sawn } \\
\text { wood }\end{array}$ & 9 & 0 & 21 & 2 & 122 & 19 & 386 & 56 & 225 & 0 & 1 & 6 & 5 & 6 & 60 & 139 & 332 & 16 & 3 & 36 & 23 & 22 & -23 & 1,440 \\
\hline 202 & $\begin{array}{l}\text { Veneer } \\
\text { sheets }\end{array}$ & 0 & 0 & 0 & 0 & 2 & 18 & 24 & 3 & 1 & 1 & 0 & 2 & 1 & 1 & 73 & 1 & 21 & 3 & 0 & 1 & 4 & 12 & 2 & 731 \\
\hline 203 & $\begin{array}{l}\text { Builders } \\
\text { carpentry }\end{array}$ & 1 & 0 & 1 & 2 & 4 & 1 & 96 & 2 & 9 & 2 & 2 & 4 & 8 & 10 & 6 & 5 & 1,045 & 16 & 7 & 7 & 34 & 15 & 14 & 540 \\
\hline 204 & $\begin{array}{c}\text { Other } \\
\text { wood } \\
\text { products }\end{array}$ & 0 & 0 & 3 & 9 & 2 & 0 & 1 & 0 & 22 & 1 & 1 & 25 & 37 & 12 & 3 & 0 & 7 & 1 & 0 & 0 & 38 & 3 & 2 & 26 \\
\hline 211 & $\begin{array}{c}\text { Pulp, } \\
\text { paper } \\
\text { \&cardboard }\end{array}$ & 9 & 3 & 5 & 32 & 10 & 6 & 9 & 1 & 1,858 & 228 & 453 & 137 & 115 & 174 & 28 & 22 & 52 & 186 & 76 & 70 & 309 & 99 & 178 & 7,596 \\
\hline 212 & $\begin{array}{c}\text { Paper } \\
\text { and } \\
\text { paperboard }\end{array}$ & 1 & 0 & 1 & 94 & 3 & 1 & 2 & 0 & 91 & 36 & 14 & 22 & 21 & 51 & 8 & 3 & 11 & 51 & 10 & 9 & 57 & 81 & 14 & 288 \\
\hline $\begin{array}{c}221 \& \\
222\end{array}$ & $\begin{array}{l}\text { Printed } \\
\text { goods }\end{array}$ & 11 & 1 & 4 & 34 & 5 & 2 & 4 & 0 & 31 & 6 & 504 & 43 & 71 & 164 & 17 & 14 & 49 & 581 & 102 & 94 & 863 & 1,110 & 128 & 567 \\
\hline 6 & $\begin{array}{l}\text { Chemical } \\
\text { industry }\end{array}$ & 203 & 30 & 78 & 207 & 27 & 30 & 86 & 2 & 649 & 21 & 46 & 1,972 & 635 & 243 & 196 & 126 & 1,655 & 712 & 888 & 107 & 516 & 1,044 & 189 & 7,875 \\
\hline 7 & $\begin{array}{c}\text { Metal } \\
\text { industry }\end{array}$ & 66 & 3 & 84 & 185 & 46 & 19 & 77 & 4 & 501 & 19 & 71 & 505 & 6,705 & 516 & 601 & 242 & 1,432 & 247 & 69 & 41 & 493 & 453 & 1,469 & 13,781 \\
\hline 8 & $\begin{array}{l}\text { Electric } \\
\text { industry }\end{array}$ & 19 & 2 & 9 & 54 & 13 & 4 & 9 & 1 & 57 & 4 & 44 & 98 & 355 & 1,867 & 80 & 31 & 328 & 175 & 94 & 92 & 534 & 252 & 765 & 17,589 \\
\hline 9 & $\begin{array}{c}\text { Other } \\
\text { manufacturing } \\
\text { industry }\end{array}$ & 3 & 1 & 2 & 10 & 3 & 1 & 8 & 0 & 11 & 2 & 26 & 39 & 235 & 34 & 653 & 5 & 241 & 294 & 187 & 20 & 277 & 760 & 1,059 & 2,895 \\
\hline 10 & Energy & 54 & 15 & 25 & 120 & 69 & 40 & 21 & 2 & 453 & 9 & 33 & 310 & 275 & 71 & 53 & 73 & 139 & 491 & 128 & 817 & 975 & 852 & 64 & 58 \\
\hline 11 & Construction & 35 & 0 & 1 & 7 & 5 & 1 & 1 & 0 & 12 & 1 & 6 & 11 & 20 & 28 & 5 & 2 & 1,464 & 181 & 426 & 2,719 & 311 & 466 & 15,125 & 41 \\
\hline 12 & $\begin{array}{l}\text { Trade, } \\
\text { hotels } \\
\text { and } \\
\text { restaurants }\end{array}$ & 556 & 44 & 17 & 275 & 333 & 60 & 37 & 2 & 430 & 11 & 83 & 350 & 683 & 375 & 242 & 90 & 2,378 & 2,700 & 1,152 & 704 & 3,990 & 15,899 & 1,387 & 1,370 \\
\hline 13 & $\begin{array}{l}\text { Transport } \\
\text { and } \\
\text { communi- } \\
\text { cation }\end{array}$ & 51 & 25 & 135 & 553 & 294 & 67 & 87 & 15 & 1,078 & 45 & 153 & 701 & 945 & 694 & 182 & 82 & 437 & 2,923 & 1,878 & 362 & 3,559 & 5,553 & 84 & 3,778 \\
\hline 14 & $\begin{array}{c}\text { Real } \\
\text { estate } \\
\text { activities }\end{array}$ & 5 & 11 & 15 & 100 & 10 & 3 & 19 & 2 & 54 & 9 & 109 & 124 & 265 & 280 & 114 & 59 & 138 & 998 & 523 & 203 & 1,999 & 17,598 & 1,481 & 0 \\
\hline 15 & $\begin{array}{c}\text { Other } \\
\text { service } \\
\text { activities }\end{array}$ & 309 & 53 & 55 & 441 & 66 & 18 & 79 & 5 & 342 & 37 & 549 & 776 & 1,466 & 2,959 & 317 & 300 & 933 & 2,509 & 1,246 & 2,358 & 8,301 & 44,789 & 2,555 & 3,352 \\
\hline \multicolumn{26}{|c|}{ SATELLITE ACCOUNTS } \\
\hline $\begin{array}{l}\text { Imported } \\
\text { products }\end{array}$ & $\mathrm{M} €$ & 252 & 33 & 143 & 1,061 & 288 & 123 & 218 & 17 & 1,498 & 129 & 415 & 6,945 & 7,685 & 7,166 & 1,840 & 897 & 1,575 & 2,858 & 1,815 & 583 & 4,219 & & & \\
\hline GHG & $\mathrm{Gg} \mathrm{CO} 2$ eq. & 7,262 & 321 & 297 & 495 & 75 & 71 & 70 & 8 & 3,766 & 16 & 32 & 8,056 & 6,797 & 531 & 347 & 19,321 & 1,767 & 2,491 & 8,551 & 426 & 4,137 & & & \\
\hline GDP & $\mathrm{M} €$ & 1,626 & 2,422 & 370 & 2,333 & 386 & 307 & 580 & 79 & 3,248 & 300 & 1,850 & 4,819 & 7,717 & 7,522 & 2,237 & 2,644 & 8,053 & 16,641 & 14,180 & 14,945 & 44,337 & & & \\
\hline Employment & 1000 my & 101 & 20 & 6 & 39 & 9 & 7 & 12 & 2 & 28 & 5 & 32 & 54 & 126 & 64 & 53 & 13 & 165 & 383 & 170 & 40 & 1,068 & & & \\
\hline Land use & $\mathrm{km} 2$ & 61,477 & 152,024 & 1,329 & 35 & 83 & 7 & 4 & 1 & 149 & 2 & 3 & 156 & 61 & 2 & 3 & 10,515 & 9 & 209 & 1,978 & 8,028 & 305 & & & \\
\hline
\end{tabular}


feedback processes in the sectors supply chain: purchases of raw materials for pulp and paper will result in the increased use of pulp and paper. Therefore the industry has a limited potential for generating its own demand, which is a property of economic key sectors [6]. In comparison to other key sectors, forest industry has less internal feedback than metal industry but more than construction industry. However the external connections are so strong that pulp and paper and sawmilling industries stimulate more economic activity than the metal or construction industries. In addition, compared to metals industry their multiplier effects are focused more on the domestic economies and not on import products.

The inclusion of environmental and social impacts makes the comparison of industries multidimensional. The direct impact intensity $B$ can be obtained by dividing the impacts (presented in the satellite accounts of Table 1) with the amount of total production (the row sum of both intermediate and final demand) of each industry. These direct intensity factors (Table 3) can be compared with the total emission multipliers, which include also the supply chain. (The total multipliers are calculated by multiplying the direct factors with the Leontief-inverse as in equation (2), but leaving out the multiplication with final demand.) The primary production industries, agriculture and energy production have the highest greenhouse gas intensities in both terms, direct and total. Similarly agriculture has the highest employment multiplier and forestry has the largest land use multiplier in both terms. For process industries however, the total multipliers are considerably larger than the direct multipliers. For the pulp and paper industry, both total greenhouse gas emissions and imports are twice as high as the direct impacts, employment is threefold and land use is more than two orders of magnitude higher than direct impacts.

One of the peculiarities of EE-IO could be observed from the comparison of land-use intensities between forest sectors. The use of economic allocation (i.e. impacts are allocated to the purchasers based on the value of the purchases) results in significantly lower land use for pulp and paper than to sawmill products. This is not caused by differences in wood production yields but in the prices of products instead. Since timber is significantly more expensive than pulpwood, a

Table 2. Columns of the Leontief Inverse for the Aggregated Input-Output Table of Finland 2005 for Selected Industries. The Elements Describe the Amount of Economic Activity Generated in the Row Industries Through the Production of One Unit of Production from the Industry in the Column

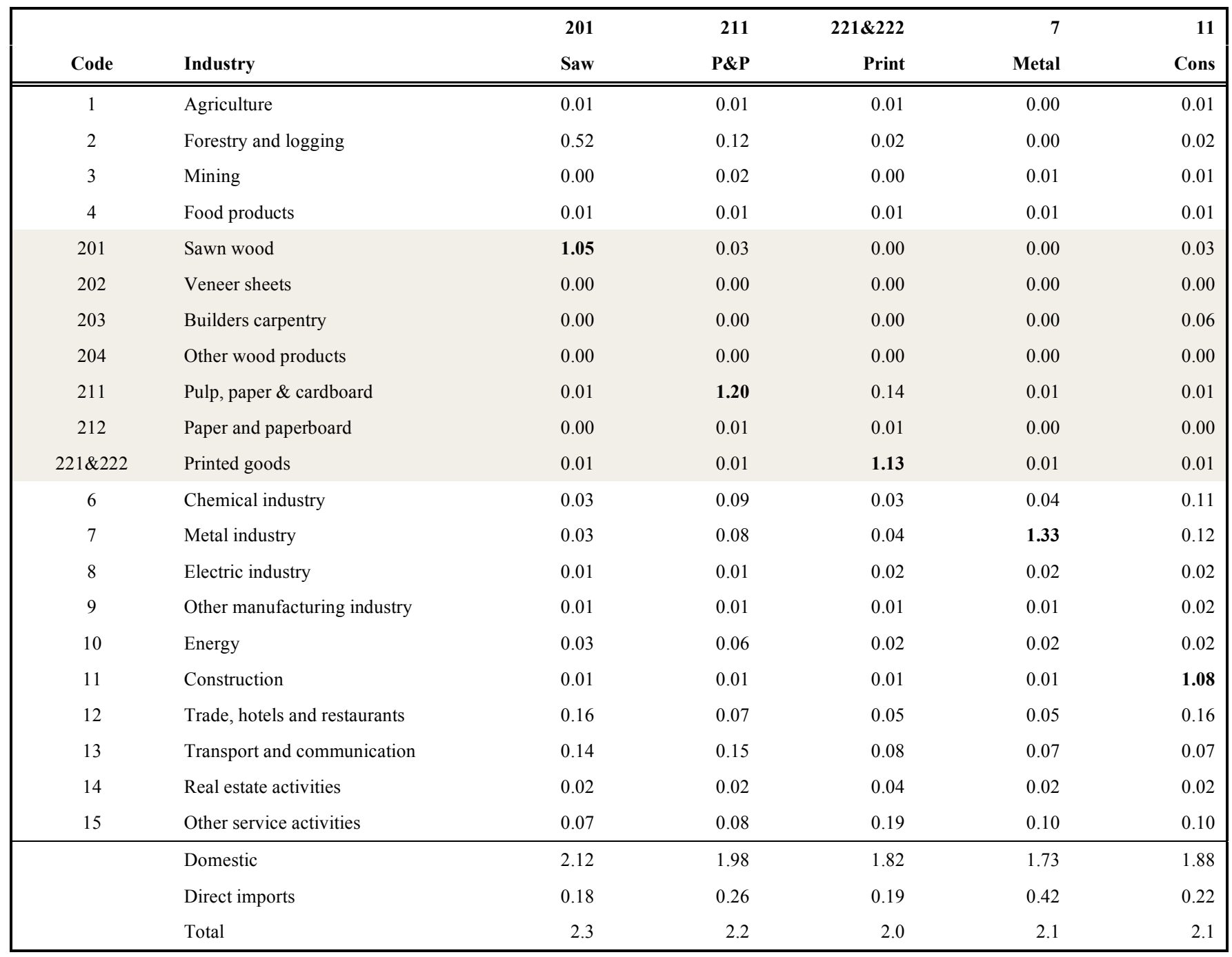


Table 3. Impact Multipliers Calculated from the Environmentally Extended Input Output Table of Finland 2005 Presented in Table 1

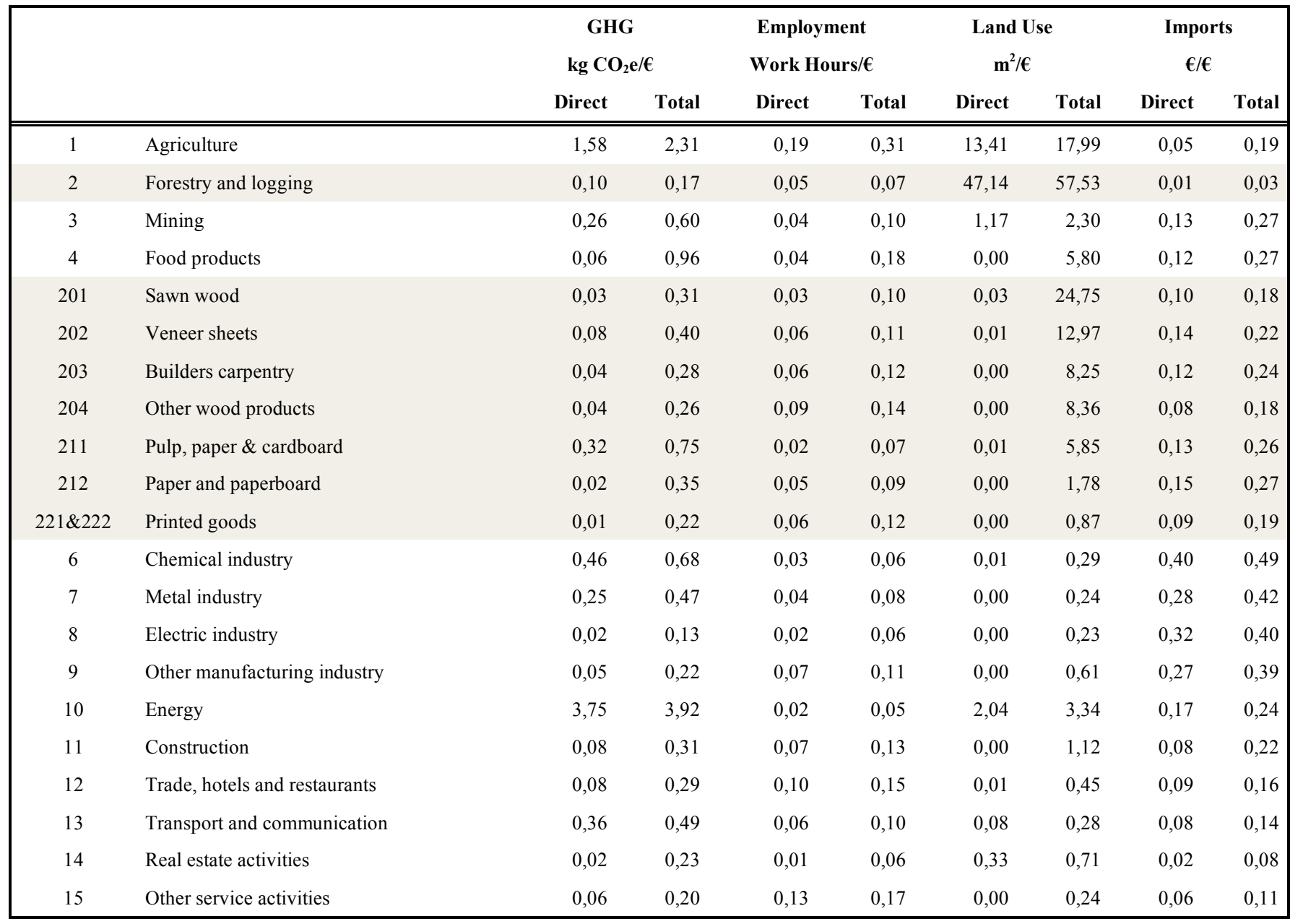

larger fraction of the land use of forestry is allocated to sawmill products than to pulp and paper manufacturing.

\section{The Role of Forest Industry in Production and Consumption Based Inventories}

Although the emissions embodied in Finnish imports [18] were not included in this study, the model based on domestic emissions can be used to study the role of forest industry in consumption based inventories through the share of export production. By dividing the emissions into final demand categories based on the amount of products purchased, an overview of the emission trade balance can be generated. The balance is incomplete, since the emissions embodied in imports are missing. However the (domestic) emissions embodied in export are valuable stand-alone indicators, since they represent the limits of local consumer choices in influencing national emissions.

The Finnish greenhouse gas emissions were $72.5 \mathrm{Mt}$ $\mathrm{CO}_{2} \mathrm{e}$ in 2005. Of this the emissions of households were 7.7 Mt, leaving 64.8 Mt for the industries [15]. Of the emissions of industries, $41 \%$ were allocated to export production, $46 \%$ to domestic consumption and the remaining $13 \%$ to investments. For the forest industries, however, the extent of export was higher. For all forest industries except the production of printed goods and paperboard, the extent of exported greenhouse gas emissions was more than $85 \%$ of the total emissions associated with the products of these industries. This high share of exported emissions was shared with the chemicals and metals industry, while services were consumed mostly within national boundaries.

When emissions were allocated from producers to products, the overall view on the main causes of emissions was changed. In the common producer-based inventory, electricity production is the main emission source, followed by transport and communication. The pulp and paper industry is shown as a relatively small emission source, especially compared to the chemicals and metals industries and transport activities. However pulp and paper production uses a significant portion of the produced chemicals, metal products, transport activities and electricity, therefore a fraction of their impact is allocated from the producers to the products of pulp and paper industry. This allocation increased the impacts of pulp and paper products into a similar order of magnitude than the impacts of producing chemicals and metals.

\section{Application to the Sustainability Assessment of Products}

Environmental input-output data can be used to fill data gaps in conventional process based life cycle assessment. 


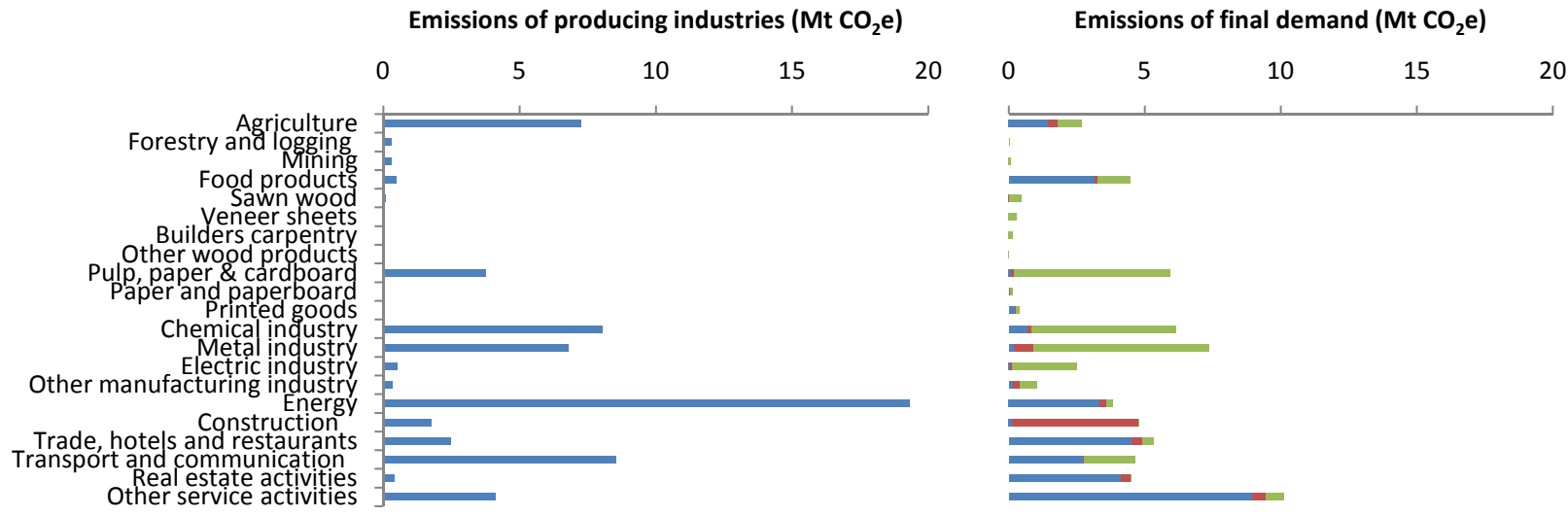

Fig. (1). The allocation of emissions reported by producing sector (left) to final demand of product categories (right). The final demand was further allocated to domestic consumption (blue), investments (red) and exports (green).

The most common source of error in process based analyses is ignoring the role of services and machinery [10,22]. Including machinery in a process-LCA is demonstrated here through an example of the environmental impacts caused by machinery in forest biomass production. For an overview of the strengths and weaknesses and the combined use of LCA and EE-IO see for example [10,22].

The costs of machinery for a small scale $(30 \mathrm{~kW}$ maximum power) wood chip heat production unit would be approximately $20 \quad 000 €$. In conventional life cycle assessment, this purchase might be ignored because of insufficient data. The order of magnitude of this purchase can however be estimated with input-output analysis by using the emission multiplier for the metals industry $(0.47 \mathrm{~kg}$ $\mathrm{CO}_{2}$ eq. $€^{-1}$, Table 3). Therefore, the emissions caused by this purchase would be approximately 9.4 tons $\mathrm{CO}_{2}$ eq., which is equal to burning three tons of light fuel oil. If using wood chips for heat instead of oil saves 8 tons of oil per annum, the emissions of machinery are quite irrelevant. However, the emissions of providing the wood for the system for 10 years amount to only about 1.5 tons of $\mathrm{CO}_{2}$ eq. (i.e. approximately $600 \mathrm{~m}^{3}$ of wood at $14 € \mathrm{~m}^{-3}$, with the emission intensity of $0.17 \mathrm{~kg} \mathrm{CO}$ eq/ $€$ from Table 3 ). Therefore the magnitude of machinery may be significant and further life cycle assessment for this part of the product system is necessary.

\section{DISCUSSION}

Through environmentally extended input-output analysis an overview of the role of forest industry in the economy was presented. Based on the results, compared to the average sector, forest industries have slightly higher economic multipliers and slightly lower employment and climate change multipliers. Land use impacts were considerably higher than for other industries and the import dependency was lower than that of other production sectors (e.g. metals, chemicals). In spite of the relatively low greenhouse gas emission intensity, the large volume of production made the pulp and paper industry one of the largest sources of greenhouse gas emissions when emissions were allocated to final products.
Export production dominated the greenhouse gas emission inventory of Finnish forestry. In a consumptionbased inventory $[18,23]$, the domestic emissions of Finnish export products would not be included in the national inventory, but would be allocated to the importers of those products instead. As pulp and paper industry is one of the largest users of electricity, also a large share of emissions from electricity would be allocated to the export products. From a policy perspective, using consumption- instead of production-based inventories would shift the national mitigation focus from industrial electricity production to services. In addition, if importing nations would choose their suppliers based on carbon-intensity, Finnish bioenergy using pulp and paper industry would have a competitive benefit over natural gas using alternatives. Therefore the consumption based inventory would seem beneficial to the Finnish government. However including the emissions embodied in imports, might offset the benefits. Although the overall trade balance of emissions was not assessed in this study, it was quantified in the ENVIMAT -project. Based on the results of that project, the difference between production and consumption based inventories for Finland was minor, although emissions embodied in both exports and imports were considerable [15]. Due to the import dependency of the Finnish production and consumption patterns, the high share of emissions embodied in exports observed in this study has little effect on the difference between consumption and production based inventories of Finnish greenhouse gas emissions.

The usefulness of EE-IO in presenting multidimensional sustainability indicators was demonstrated. However in this study, no effort was made to connect the indicators into decision making and the indicators were presented separately. However, in real-life decision making conflicting indicators and tradeoffs between the dimensions of sustainability need to be resolved (e.g. is land use or employment more critical in a given supply chain). Therefore applying the tools of multi-criteria decision making (MCDA) [32,33] to environmentally extended inputoutput models would be an interesting topic of further research. In MCDA, the idea is to estimate the overall utility of different alternatives through weight coefficients for the sustainability indicators. Since several environmental, 
economic and social indicators have been connected to EEIO, analyzing their relative importance would facilitate the interpretation of results for decision making.

Another interesting topic of future research related to decision making is the analysis of the uncertainties involved in EE-IO. Among others, uncertainties are related to selected system boundaries, estimated parameters and selected models [34]. In the case presented in this study, system boundary uncertainties are increased through aggregation and excluding the emissions of imports, parameter errors are introduced in the balancing of national accounts and choice uncertainty is introduced in the selection of indicators. Introducing weighting factors from decision analysis would add to the degree of uncertainty even more. More generally when making sustainability assessments based on national accounts, the level of uncertainty is expected to be high, given the complexity of the decision problem. If EE-IO would be used as a background for decision making in forest chain management, quantifying and reducing the uncertainties through models would be a priority. Monte Carlo simulation is commonly used in life cycle assessment [34] to carry out the uncertainty analysis and associated statistical analyses [35]. In the field of MCDA sophisticated techniques for measuring and analyzing uncertainties in terms of actual decision making have been developed [36,37]. The utilization of these techniques could benefit the use of EE-IO in multidimensional sustainability assessments.

\section{CONCLUSION}

Environmentally extended input-output analysis (EE-IO) was shown to be well suited to present the role of forest industries in producing both economic goods and environmental bads in connection with the rest of the economy. For most cases, the multiplier effects caused by the supply chain were considerably larger than those produced directly on the sector. This indicated that the forest industries are strongly connected with the rest of the economy. The analysis of emissions embodied in export revealed that for the forest industries, most of the environmental impacts are caused by production for export markets. Therefore local consumer choices have limited capability to control the overall emissions and land use impacts of Finnish forest industries through market mechanisms.

EE-IO was demonstrated to be applicable in simultaneously assessing the multiple dimensions of sustainability. This property could be further strengthened by using techniques from multi-criteria decision making.

\section{REFERENCES}

[1] Ortiz O, Castells F, Sonnemann G. Sustainability in the construction industry: A review of recent developments based on LCA. Constr Build Mater 2009; 23 (1): 28-39.

[2] Soimakallio S, Antikainen R, Thun R. Assessing the sustainability of liquid biofuels from evolving technologies. A Finnish approach. VTT Research Notes 2482/2009; Available from: http://www.vtt.fi/inf/pdf/tiedotteet/2009/T2482

[3] United Nations. Drafts Agenda 21, Rio Declaration Forest Principles. United Nations 1992.

[4] Matthews HS, Hendrickson CT, Weber CL. The importance of carbon footprint estimation boundaries. Environ Sci Technol 2008; 42(16): 5839-42.
[5] Guinée JB. Handbook on life cycle assessment: operational guide to the ISO standards. $1^{\text {st }}$ ed. USA: Springer 2002.

[6] Oosterhaven J. On the definition of key sectors and the stability of net versus gross multipliers [Internet]. 2004 [cited 2010 Jan 18]; Available from: http://econpapers.repec.org/paper/dgrrugsom/04c01.htm

[7] Ten Raa T. The economics of Input-output analysis. New York: Cambridge University Press 2006.

[8] Hendrickson CT, Matthews HS. Environmental life cycle assessment of goods and services: an input-output approach. USA: RFF Press 2006.

[9] Nakamura S, Kondo Y. Waste input-output analysis: concepts and application to industrial Ecology. $1^{\text {st }}$ ed. USA: Springer 2009.

[10] Suh S, Lenzen M, Treloar GJ, et al. System boundary selection in life-cycle inventories using hybrid approaches. Environ Sci Technol 2004; 38(3): 657-64.

[11] Leontief W. Environmental repercussions and the economic structure: An input-output Approach. Rev Econ Stat 1970; 52(3): 262-71.

[12] de Haan M, Keuning SJ. Taking the environment into account: The NAMEA approach. Rev Income wealth 1996; 42(2): 131-48.

[13] Stahmer, C, Kuhn, M, Braun, N. Physical input-output tables for Germany, 1990. European Commission 1998.

[14] Nansai K, Moriguchi Y, Tohno S. Compilation and application of japanese inventories for energy consumption and air pollutant emissions using input- output tables. Environ Sci Technol 2003; 37(9): 2005-15.

[15] Seppälä J, Mäenpää I, Koskela S, et al. Suomen kansantalouden materiaalivirtojen ympäristövaikutusten arviointi ENVIMATmallilla (Environmental impacts of material flows caused by the Finnish economy). The Finnish Environment Institute (SYKE). 2009; p. 20.

[16] Hertel T, Walmsley T. GTAP 7 Data Base Documentation - Chapter 1: Introduction [Internet]. 2008 [cited 2010 Jan 18]. Available from: http://www.gtap.agecon.purdue.edu/resources/res display.asp?Recor $\mathrm{dID}=2895$

[17] Suh S, Huppes G. Methods for life cycle inventory of a product. J Cleaner Prod 2005;13(7): 687-97.

[18] Peters GP, Hertwich EG. $\mathrm{CO}_{2}$ embodied in international trade with implications for global climate policy. Environ Sci Technol 2008; 42(5): 1401-7.

[19] Eurostat. Eurostat Manual of Supply, Use and Input-Output Tables [Internet]. Eurostat; 2008. Available from: http://epp.eurostat.ec.europa.eu/cache/ITY_OFFPUB/KS-RA-07013/EN/KS-RA-07-013-EN

[20] Eurostat. European System of Accounts ESA 95 [Internet]. [cited 2010 Jan 18]; Available from: http://epp.eurostat.ec.europa.eu/portal/ page/portal/esa95_supply_use_input_tables/introduction

[21] OECD. Input-Output Tables (2009) [Internet]. [cited 2010 Jan 18]; Available from: http://www.oecd.org/document/3/0,3343, en_2649_34445_38071427_1_1_1_1,00.html

[22] Lenzen $\bar{M}$. Errors in conventional and input-output-based life-cycle inventories. J Indust Ecol 2001; 4(4): 127-48.

[23] Peters GP. From production-based to consumption-based national emission inventories. Ecol Econ 2008; 65(1): 13-23.

[24] Heijungs R, Suh S. The computational structure of life cycle assessment. USA: Kluwer Academic Publishers 2002.

[25] Dietzenbacher E, Los B. Structural decomposition techniques: sense and sensitivity. Econ Sys Res 1998; 10(4): 307.

[26] Lenzen M. Environmentally important paths, linkages and key sectors in the Australian economy. Struct Change Econ Dyn 2003; 14(1): 1-34.

[27] Statistics Finland. Input-output tables at basic prices 2000-2005 [Internet]. [cited 2010 Jan 18]; Available from: http://pxweb2.stat.fi/database/StatFin/kan/pt/pt_en.asp

[28] Statistics Finland - Statistics by topic - Production of electricity and heat [Internet]. [cited 2010 Jan 18]; Available from: http://www.stat.fi/til/salatuo/tau_en.html

[29] Solomon S, Qin D, Manning $\bar{M}$, et al. Climate change 2007: the physical science basis. New York: Cambridge University Press Cambridge 2008.

[30] Härmä P, Teiniranta R, Torna M, Repo R, Järvenpää E, Kallio M. Production of CORINE2000 land cover data using calibrated LANDSAT 7 ETM satellite image mosaics and digital maps in Finland. In: 2004 IEEE International Geoscience and Remote Sensing Symposium, 2004. IGARSS'04 2004. 
[31] Mattila T, Nissinen A, Seppälä J, Mäenpää I. Land use impacts of industries and products in the Finnish economy. Biomass \& Bioenergy (Accepted).

[32] Keeney RL, Raiffa H. Decisions with multiple objectives: Preferences and value tradeoffs. UK: Cambridge University Press 1993.

[33] Leskinen P, Kangas J. Multi-criteria natural resource management with preferentially dependent decision criteria. J Environ Manage 2005; 77(3): 244-51.
[34] Lloyd SM, Ries R. Characterizing, propagating, and analyzing uncertainty in life-cycle assessment. J Indust Ecol 2007; 11: 16180 .

[35] Saltelli A, Ratto M, Andres T, et al. Global sensitivity analysis: the primer. USA: Wiley-Interscience 2008.

[36] Alho JM, Kangas J. Analyzing uncertainties in experts' opinions of forest plan performance. For Sci 1997; 43(4): 521-28.

[37] Leskinen P, Hujala T, Tikkanen J, et al. Adaptive decision analysis in forest management planning. For Sci 2009; 55(2): 95-108.

Received: October 23, 2009

Revised: January 18, 2010

Accepted: February 2, 2010

(C) Mattila et al.; Licensee Bentham Open.

This is an open access article licensed under the terms of the Creative Commons Attribution Non-Commercial License (http://creativecommons.org/licenses/bync/3.0/) which permits unrestricted, non-commercial use, distribution and reproduction in any medium, provided the work is properly cited. 